\title{
Extraction-Spectrophotometric Determination of Lidocaine Hydrochloride in Pharmaceuticals
}

\author{
Lazeeza Sattar Omer ${ }^{1}$, Rasul Jameel Ali ${ }^{2}$ \\ ${ }^{1}$ Department of Pharmaceutical Chemistry, College of Pharmacy, Hawler Medical University, Erbil, Kurdistan, Iraq. \\ ${ }^{2}$ Department of Clinical Biochemistry, College of Health Sciences, Hawler Medical University, Erbil, Kurdistan, Iraq. \\ Correspondence: Lazeeza Sattar Omer, Department of Pharmaceutical Chemistry, College of Pharmacy, Hawler Medical \\ University, Erbil, Kurdistan, Iraq.
}

Received: May 21, 2017

doi:10.5539/ijc.v9n4p49
Accepted: September 19, 2017 Online Published: September 29, 2017

URL: https://doi.org/10.5539/ijc.v9n4p49

\begin{abstract}
Simple, selective and highly detectable spectrophotometric method has been developed and validated for the determination of Lidocaine hydrochloride in standard and commercial solutions. The method is based on the formation of a soluble colored Lidocaine hydrochloride-eriochrome black $\mathrm{T}$ ion-pair complex at $\mathrm{pH} 1.80$. The colored complex was extracted quantitatively into chloroform and measured at $508 \mathrm{~nm}$. Beer's law was obeyed in the concentration range of $0.10-10 \mathrm{mg} \mathrm{L}^{-1}$ with molar absorptivity of $2.3623 \times 10^{4} \mathrm{~L} \mathrm{~mol}^{-1} \mathrm{~cm}^{-1}$. The limits of detection and quantification were 0.024 $\mathrm{mg} \mathrm{L}^{-1}$, and $0.100 \mathrm{mg} \mathrm{L}^{-1}$ respectively. Using Job's continuous variations method, the stoichiometry of the ion-pair complex was found to be 1:1. Intra-day accuracy and precision of the method were estimated with a relative error $(0.57 \%)$, and the relative standard deviation (0.25-1.23). This developed method has been successfully employed to determine concentration of Lidocaine hydrochloride in injection and spray without interference by the common co-formulated substances. The numerical results obtained using both proposed and official methods were in concordance with each other.
\end{abstract}

Keywords: Lidocaine hydrochloride (LD-HCL), Spectrophotometry, eriochrome black T (EBT), ion-pair

\section{Introduction}

Lidocaine or Xylocaine hydrochloride (LD-HCl), an amino amide is non-irritating, and cause lesser allergic reactions than esters. It acts as a local anesthetics by interfering with the propagation of peripheral nerve impulses by blocking the sensation of pain. LD-HCl is, also employed in spinal anesthesia and as an antiarrhythmic drug (Lemke, \& Williams, 2008)

Lidocaine is a weak base and to be water soluble salt and an injectable form the addition of hydrochloride is required (Martindale, 2007)

LD-HCl, chemical name,2-(diethyl amino)-N-(2,6-dimethylphenyl) acetamide mono hydrochloride, $\mathrm{C}_{14} \mathrm{H}_{22} \mathrm{~N}_{2} \mathrm{O}$,. $\mathrm{HCl}$, and has a molecular weight of $270.8 \mathrm{~g} / \mathrm{mol}$. LD-HCL hydrate is a white, crystalline powder, odorless and has a slightly bitter taste. LD-HCL is highly soluble in water or in ethanol, soluble in chloroform, and practically insoluble in ether (Lemke, \& Williams, 2008).

Its aqueous solution is stable because of the stability of amide functional group. It has the following structural formula as illustrated in Fig 1.1.

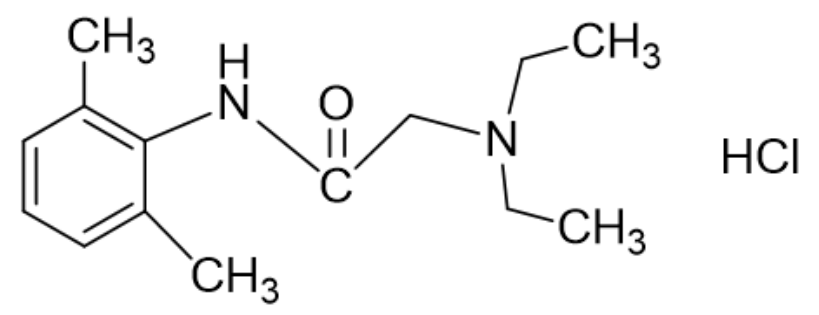

Figure 1.1. The chemical structure of Lidocaine hydrochloride 
Structurally, lidocaine can be viewed as an open-chain analog of isogramine and thus is a bioisosteric analog of isogramine which is 3-(dimethyl aminomethyl)-indole. Advantages of lidocaine derivatives over procaine derivatives are that they are more stable to hydrolysis and can be sterilized by autoclaving. It is more potent, has lower side effects such as less local irritation in comparison to procaine derivatives, and can be used as alternatives for patients' sensitive to procaine type anesthetic. A local anesthetic molecule, which is composed of three moieties: 1) aromatic ring; 2) intermediate ester or amide chain; and 3) terminal chain Fig. 1.2 (Yagiela, Dowd, Johnson, Mariotti, \& Neidle, 2011).

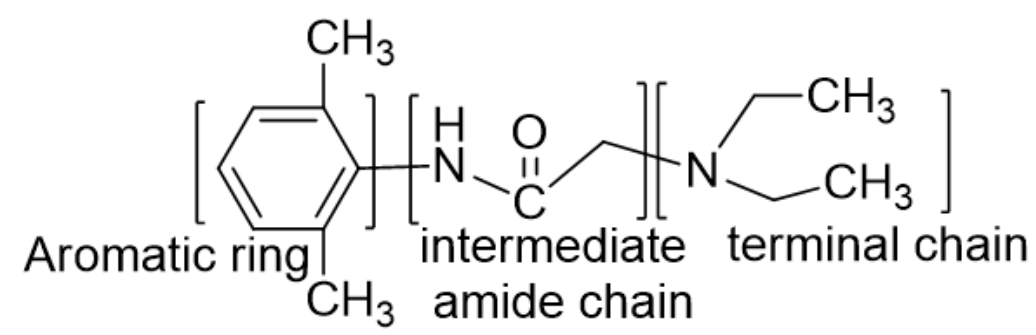

Figure 1.2. The chemical composition of Lidocaine

Depending on the type of aromatic chain, local anesthetic can be divided into two main classes: amide (e.g., articaine, bupivacaine, lidocaine, $\&$ ropivacaine) and ester (e.g., benzocaine, cocaine, proparacaine, \& tetracaine). Compared to ester anesthetics, amide local anesthetics are more commonly used in clinics because of relatively lower allergic reactions of human associated to amide local anesthetics (Railan \& Alster, 2007; Berkman, MacGregor, \& Alster, 2012). Apart from that, amide local anesthetics have better lipid solubility, higher potency and longer duration of action than the ester type (Becker, \& Reed, 2006). In this study the chromogenic reagent is Eriochrome Black $\mathrm{T}$ [Sodium 1-(1-hydroxy-2-naphthylazo)-6-nitro-2-naphthol-4-sulphonate $\left.\left(\mathrm{NaH}_{2} \mathrm{In}\right)\right]$ which is acidic dye of azo (-N=N-) class that contain $-\mathrm{SO}_{3} \mathrm{Na}$ group allowing it to be soluble in water (VOGE L' s, 1989).

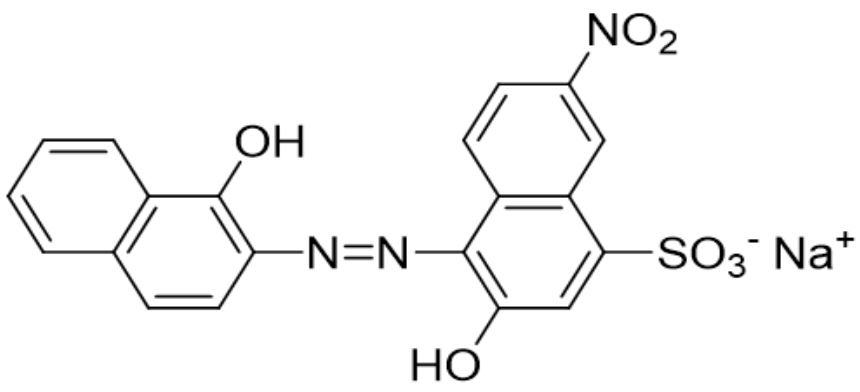

Figure 1.3. The chemical structure of Eriochrome Black T

At low pH (e.g. 1.8) EBT is a completely ionized forming anion $\left(\mathrm{H}_{2} \mathrm{In}-\right)$ which react with positive protonated drug resulting in an ion-association complex formed by electrostatic attraction between cationic drugs and the anion of the dye. This ion-association complex which is a hydrophobic species is extracted using organic solvents. The concentration of the colored ion- pair in the organic phase is measured spectrophotometrically.

Various analytical techniques for LD-HCL determination in biological and pharmaceutical samples have been published, including the chromatographic methods, gas chromatography(GC) determination of LD-HCl in whole blood (Keenaghan, 1968), (Edhorn, 1971), (Asada, 1979) (Hattori,Yamamoto, \& Yamada, 1991) (Watanabe, Namera, Yashiki, Iwasaki, \& Kojima, 1998), from serum (Kruczek, 1981)(Prat \& \& Bruguerolle, 1986) (Baniceru, Croitoru, \& Popescu, 2004), from plsma (Björk, Pettersson, \& Osterlöf, 1990), in human plasma and urine (Ohshima\& Takayasu, 1999), in human urine (Koster, Hofman, \& Jong, 1998), to distinguish the drug from its thermal degradation produts (Stavchansky, Eghbali \& Geary, 1987), in pharmaceutical preparations (Tarli P, Benocci \& Neri, 1969), and Forced Degradation of Lidocaine $\mathrm{HCl}$ by NMR Spectroscopy and GC-FID Methods(Kadioglu, Atila, Serdar, Gultekin, \& Alcan, 2013), thin-layer chromatography (TLC)for the Determination of Hydrocortisone Acetate and Lidocaine in a Pharmaceutical Preparation (Dołowy, Kulpińska-Kucia, \& Pyka, 2014), high-performance liquid chromatography (HPLC) and TLC (Živanović, Živanov-Stakić, \& Radulović, 1998) (Abdelwahab, Nouruddin, Abdelkawy, Emam, 2016), HPLC, in plasma with solid phase extraction and UV detection (Kang, Jun, \& McCall, 1999), in pharmaceuticals (Smith \& Nuessle, 1981) (Waraszkiewicz, Milano, \& DiRubio, 1981) (Atay \& Öztop, 1997) (Parissi-Poulou \& Panderi, 1999) (Gebauer, McClure, \& Vlahakis, 2001) (Liawruangrath, Liawruangrath, \& Pibool, 2001) (Malenovic, Medenica, Ivanovic, Jancic, \& Markovic, 2005) (Zivanovic, Zecevic, Markovic, Petrovic, \& Ivanovic, 2005) (Salas, Talero, Rabasco, \& González, 2008) (Stojanović, Malenović, Marković, Ivanović, \& Medenica, 2010)(Shaalan \& Belal, 2010) (Belal \& Haggag, 2012) 
(Drljača et al, 2016), liquid chromatography (LC) for pharmaceuticals assay (Youngvises, Liawruangrath, \& Liawruangrath, 2003) (Mohammad 2009) (Pendela, Kahsay, Baekelandt, Schepdael, \&Adams, 2011), electrophoretic method (Candioti, Robles, Mantovani \& Goicoechea, 2006), electro analytical method (Abrutis, Radulescu, Baiulescu \& Coşofreţ, 1985), (Hassan \& Ahmed, 1986), (Oliveira, Salazar-Banda, Ferreira, Oliveira, \& Avacaa, 2007) (Rahbar, Ramezani, \& Babapour, 2015), atomic absorption spectrophotometry- indirect methods ( Nerín, Garnica \& Cacho, 1991) (El-Ries, Abou Attia, Abdel-Gawad, \& Abu El-Wafa, 1994), Spectrophotometric methods for pharmaceuticals detection ,using cis-aconitic anhydride (Feldmann, and Koehler, 1959), bromocresol green (Ismaiel, Yassa, \& Gad-El-Rub, 1975), haematoxylin reagent in the presence of boric acid (Saleh \& Askal, 1995) , Ion-pair formation Oxidation by Ce (IV) (Rizk, Issa, Shoukry \& Atia, 1997), bromocresol green using flow injection analysis (Němcová, Rychlovský, Tománková \& Živanovič, 2001), p-benzoquinone (Amin \& El-didamony, 2003), partial least - squares multivariate calibration (Aksu, Bozdoğan \& Kunt, 2006), with Eosin Methylene Blue (Zong-hui, Li-jun, \& Rong, 2007), in binary mixture using novel mathematical methods namely amplitude subtraction and amplitude factor, in addition to ratio subtraction coupled with first derivative(Lotfy, Tawakkol, Fahmy \& Shehata, 2013), liquid-liquid extraction-fluorimetry (Wen-ting; Xiao-lan, \& Shu-mei, 2014), and liquid chromatographic official method for the determination of LD-HCL in pharmaceutical preparations is cited in the United States Pharmacopeia (NF-27, 2008). The objective of this study is to develop accurate, precise, sensitive, selective, reproducible, easy and low cost spectrophotometric method for the determination of $\mathrm{LD} \mathrm{HCl}$ in bulk analysis and in pharmaceutical samples.

\section{Experimental Part}

\subsection{Apparatus}

A Perkin Elmer Lambda 25 double beam UV-visible spectrophotometer was used to perform spectral runs. All other absorbance measurements were made on JENWAY 6305 UV-visible spectrophotometer with $1 \mathrm{~cm}$ path length glass cuvette. The $\mathrm{pH}$ was measured with HANNA $\mathrm{pH}$ meter.

\subsection{Material}

All chemicals used in the present study were of analytical grade. LD-HCL was kindly supplied by Awamedica pharmaceutical Industries Company (Hawler, Kurdistan, Iraq). 'The pharmaceutical samples used in this study were lidocaine B (Braun) 2\%(A), lidocaine $\mathrm{HCl}$ (Shahid Ghazi pharmaceutical Co. Tabriz, Iran) 2\% (B), lidocaine injection BP (ROTEXMEDICATRITTAU, Germany) $1 \%(\mathrm{C})$, and lidocaine HCl BP spray (Philadelphia Pharmaceutical Company, Jordan) $10 \%$ (D).

\subsection{Reagents}

\subsubsection{LD-HCl Stock Solution $(100 \mathrm{mg} / \mathrm{L})$}

$0.01 \mathrm{gm}$ of LD-HCL was dissolved in water and diluted to $100 \mathrm{ml}$ in a volumetric flask. A series of standard solutions from stock were prepared by a suitable dilution of stock standard solution with distilled water. The stock solution remained unchanged for 1 month when kept refrigerated.

\subsubsection{EBT Solution $(0.01 \%)$}

A stock solution of EBT was prepared by dissolving the appropriate weight in distilled water and was diluted to $100 \mathrm{ml}$ with distilled water. This solution was prepared fresh in minimal quantities on the day of testing.

\subsubsection{Buffer Solution}

Buffer solutions of potassium chloride- hydrochloric acid ( $\mathrm{pH} 1.5-\mathrm{pH} 4.2)$, sodium acetate-hydrochloric acid ( $\mathrm{pH}$ 1.99$\mathrm{pH}$ 4.92), sodium acetate-acetic acid $(\mathrm{pH} 2.8-\mathrm{pH} 6.0)$ and potassium hydrogen phthalate-hydrochloric acid ( $\mathrm{pH} 2.0-\mathrm{pH}$ 6.0) were prepared fresh using standard methods.

\subsection{Preliminary Tests}

An appropriate volume $2.5 \mathrm{~mL}$ of $100 \mathrm{mg} / \mathrm{L}$ standard drug solution was pipetted into a $25 \mathrm{~mL}$ volumetric flask. Subsequently $0.5 \mathrm{ml}$ of $0.1 \%$ EBT solution and $3 \mathrm{~mL}$ buffer solution $\mathrm{pH} 2.2$ were added. The mixture was diluted to the mark with distilled water, mixed well, and transferred to a separating funnel. The funnel was shaked with $2 \times 5 \mathrm{~mL}$ organic solvent for 2 mints, then allowed to stand for clear separation of the two phases. The combined chloroform layers were transferred into a cuvette. ). The reagent blank was prepared in a similar way without drug solution.

\section{Results and Discussion}

\subsection{Absorption Spectra}

Under the conditions of preliminary tests of the proposed method, the absorbance/wave length spectra of the colored ion- pair complex was scanned between the ranges of 400-800 nm against the blank solution. The colored ion-pair complex showed maximum absorbance at $508 \mathrm{~nm}$. In the blank experiment using blank, the color of chloroform layer 
remained the same, thus the reagent blank did not show absorption at $508 \mathrm{~nm}$, as seen in Fig. 2.1.

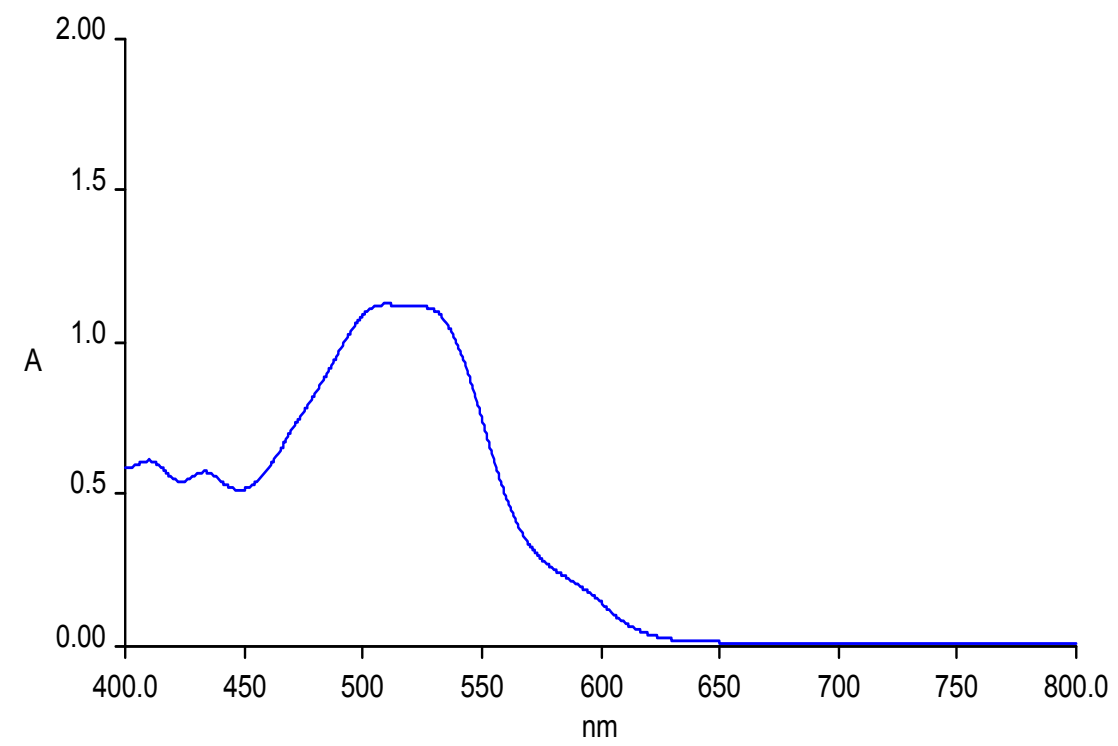

Figure 2.1. Absorption spectra of LD -EBT against reagent blank treated in the preliminary tests.

\subsection{Reaction Mechanism}

The chemical structure of LD-HCl (colorless solution) molecule consists of three parts the third part is a tertiary amine $\left(\mathrm{R}_{3} \mathrm{~N}:\right) /$ hydrophilic basic group and proton acceptor. At low $\mathrm{pH}$, nitrogen is able to share a nonbonding pair of electrons to form a bond with the acidic proton. Acid base reaction forming protonated LD (conjugate acid /charged positively) attracts anion of acidic dye present in the solution forming ion- pair neutral species. As the extraction was performed, this ion- pair neutral species is extracted into chloroform phase while the chloroform phase changes color from clear to red. In the blank experiment, the color of the chloroform layer remains unchanged. The mechanism of ion- pair formation and extraction is described in scheme 1. 


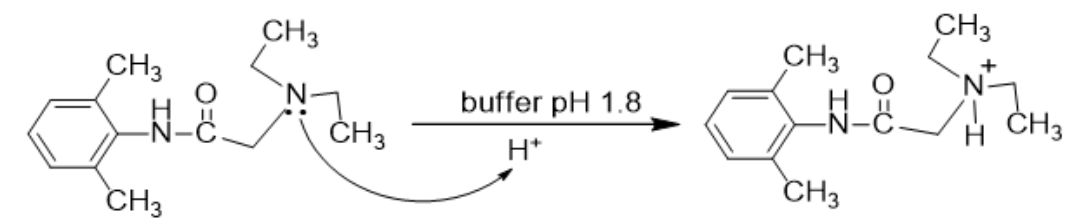

Lidocaine/Base

Protonated Lidocaine/conjgate acid<smiles>O=[N+]([O-])c1ccc2c(N=Nc3ccc4ccccc4c3O)c(O)cc(S(=O)(=O)O)c2c1</smiles>

Eriochrome Black T<smiles>O=[N+]([O-])c1cc(O)c(N=Nc2ccc3ccccc3c2O)c2ccc([N+](=O)[OH2+])cc12</smiles>

Anion Eriochrome Black T<smiles>CC[N+](C)(CC)CC(=O)Nc1c(C)cccc1C</smiles>

Protonated Lidocaine

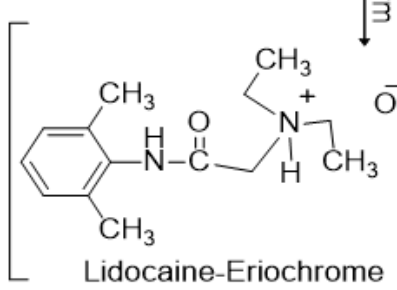<smiles>O=S(=O)([O-])c1cc(O)c(N=Nc2ccc3ccccc3c2O)cc1O</smiles>
Anion Eriochrome Black T

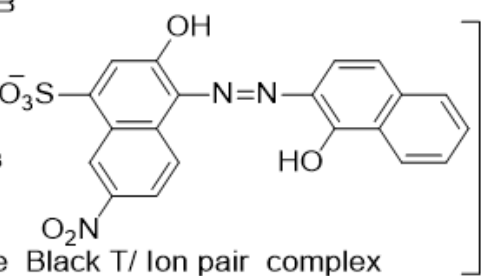

Scheme 1. Probable mechanism for the formation of 1:1 LD-EBT

\subsection{Ion-Pair Composition}

The ion-pair complex composition was studied by continuous variations Job's method using variable LD-HCl and dye concentrations. The result in Fig 3.1 indicates 1:1 (LD-HCl: EBT) ion- pair complex formation through the electrostatic attraction between the positive protonated lidocaine and the anion of EBT.

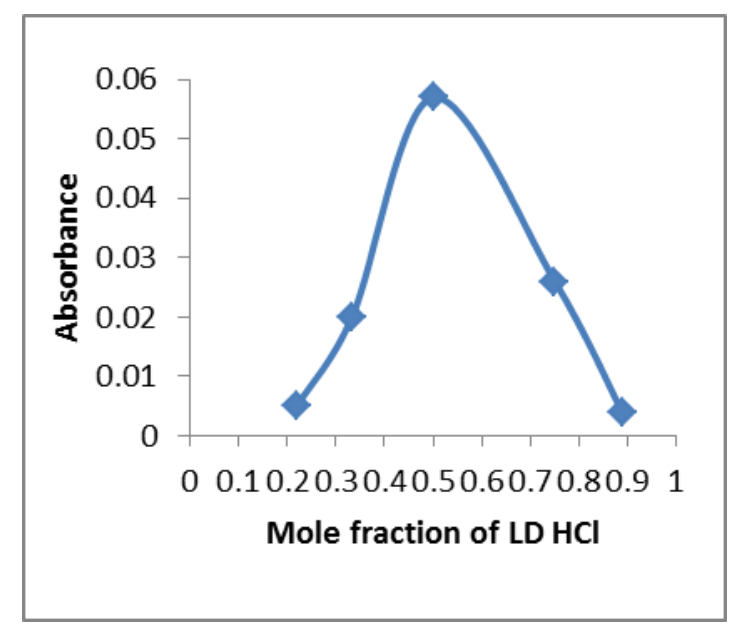

Figure 3.1. Job plot of LD-EBT ion-pair in chloroform at $508 \mathrm{~nm}$

\subsection{Optimum Conditions}

To achieve the optimum conditions for this method, the following parameters were studied. 


\subsubsection{Effects of $\mathrm{pH}$ on the Ion-Pair Formation}

The effect of $\mathrm{pH}$ was studied by extracting the colored ion pair in the presence of various buffers such as potassium chloride- hydrochloric acid ( $\mathrm{pH}$ 1.5- $\mathrm{pH} 4.2)$, sodium acetate-hydrochloric acid ( $\mathrm{pH}$ 1.99-ph4.92), sodium acetate - acetic acid $(\mathrm{pH} 2.8-\mathrm{pH} 6.0)$ and potassium hydrogen phthalate- hydrochloric acid ( $\mathrm{pH} 2.0-\mathrm{pH} 6.0$ ). It was observed that the maximum color intensity and highest absorbance values were recorded in potassium chloride- hydrochloric acid $(\mathrm{pH}$ 1.8). The results are shown in Table 3.1.

Table 3.1. Effects of $\mathrm{pH}$ on the ion-pair formation

\begin{tabular}{llll}
\hline $\mathrm{pH}$ & Absorbance & $\mathrm{pH}$ & Absorbance \\
\hline 1.0 & 0.744 & 5.6 & 0.088 \\
1.8 & 0.898 & 6.0 & 0.043 \\
2.2 & 0.438 & 6.4 & - \\
3.6 & 0.428 & 6.8 & 0.029 \\
4.0 & 0.422 & 7.3 & - \\
4.5 & 0.133 & 7.6 & 0.021 \\
5.0 & 0.574 & 8 & 0.025 \\
\hline
\end{tabular}

\subsubsection{Effect of Volume of Buffer Solution}

The maximum color intensity and highest absorbance values were observed in potassium chloride- hydrochloric acid buffer solution at $\mathrm{pH}$ 1.8. The effect of different volumes of this buffer solution to obtain maximum sensitivity was investigated. The volume of the buffer solution required to obtain maximum absorption was $2.0 \mathrm{~mL}$, as shown in table (3.2).

Table 3.2. Effect of volume of buffer solution on the ion-pair formation

\begin{tabular}{ll}
\cline { 2 - 2 } Volume $(\mathrm{mL})$ & Absorbance \\
\cline { 2 - 3 } 0.5 & 0.016 \\
1.0 & 0.053 \\
1.5 & 0.018 \\
2.0 & 0.880 \\
2.5 & 0.740 \\
3.0 & 0.750 \\
3.5 & 0.770 \\
4.0 & 0.790 \\
\hline
\end{tabular}

\subsubsection{Solvent Selection for Extraction.}

The effect of extraction solvents (2-Propanol, ethyl acetate anhydrous, butanol, chloromethane, ether and carbon tetrachloride) on LD-EBT ion-pair complex as examined. The highest absorbance of the LD-EBT ion-pair was recorded in chloroform .The ion-pair complex failed to be extracted in carbon tetrachloride, and ethyl acetate. The absorbance values of each solvent are recorded in, Table 3.3. Chloroform was selected as the most appropriate solvent for the extraction of the ion-pair.

Table 3.3. Absorbance values of LD-EBT ion-pair in different solvents.

\begin{tabular}{ll}
\cline { 2 - 2 } Solvent & Absorbance \\
\cline { 2 - 2 } 2-Propanol & 0.029 \\
Butanol & 0.682 \\
Ethyl acetate anhydrous & -0.039 \\
Chloromethane & 0.532 \\
Ether & 0.023 \\
Chloroform & 0.886 \\
Carbon tetrachloride & - \\
\hline
\end{tabular}

\subsubsection{Effect of EBT $(0.01 \%)$ Volume}

The effect of EBT volume on the color intensity of LD-EBT ion-pair was investigated in the range of $0.1 \mathrm{~mL}-1.1 \mathrm{~mL}$. As 
outlined in Table (3.4), the absorbance of LD EBT ion- pair was directly proportional to the volume EBT up to $0.3 \mathrm{~mL}$. Above $0.3 \mathrm{~mL}$, the absorbance remained approximately constant. At higher concentrations, the colored solution became opaque, therefore $0.3 \mathrm{~mL}$ of $0.01 \%$ EBT was taken as the optimum volume for the formation of the clear colored LD -EBT ion- pair complex.

Table 3.4. Effect of $0.01 \%$ EBT volume on the ion-pair formation

\begin{tabular}{ll}
\hline Volume of $0.01 \%$ EBT $(\mathrm{mL})$ & Absorbance \\
\hline 0.1 & 0.1435 \\
0.3 & 0.889 \\
0.5 & 0.890 \\
0.7 & 0.870 \\
0.9 & 0.877 \\
1.1 & 0.892 \\
\hline
\end{tabular}

\subsubsection{Effect of Reaction Time}

The effect of the reaction time on the development of LD-EBT ion-pair and its stability was investigated. The ion- pair was stable immediately after mixing LD with EBT at room temperature, remained stable for at least 1.5 hours. Table 3.5 shows the absorbance of the ion- pair complex over different time period.

Table 3.5. Stability of LD-EBT ion-pair

\begin{tabular}{llll}
\hline Time $(\mathrm{min})$ & Absorbance & Time $(\mathrm{min})$ & Absorbance \\
\hline 1.00 & 0.885 & 25.0 & 0.800 \\
2.00 & 0.897 & 30.0 & 0.795 \\
3.00 & 0.898 & 40.0 & 0.789 \\
4.00 & 0.889 & 50.0 & 0.790 \\
5.00 & 0.881 & 60.0 & 0.794 \\
10.0 & 0.871 & 75.0 & 0.801 \\
15.0 & 0.836 & 90 & 0.741 \\
20.0 & 0.832 & & \\
\hline
\end{tabular}

\subsubsection{Effect of Shaking Time and Temperature}

In two different sets of experiments, the effect of shaking time during extraction of the ion- pair complex in chloroform was studied between the time ranges of $0.5 \mathrm{mints}-3.5$ mints. In the first set of experiments, the maximum absorbance of the ion- pair was obtained between 1.0 min shaking and above, up to 3.5 mints. Between 1.0 mins-3.5 mints, the absorbance remained fairly constant. In the second sets of experiments, the effect of temperature on the absorbance was examined in the range of $20^{\circ} \mathrm{C}-80{ }^{\circ} \mathrm{C}$. The results showed that temperature had little influence on the absorbance of the LD-EBT ion-pair complex. Therefore the absorbance was measured at room temperature $\left( \pm 25^{\circ} \mathrm{C}\right)$ for subsequent experiments.

\subsubsection{Extraction Efficiency}

Extraction efficiency to measure how readily LD-EBT ion-pair species was extracted to chloroform layer was calculated. After the first extraction, the aqueous layer was re-extracted with another portion of chloroform. Table 3.6 shows molecular absorbance values for the extracted LD-EBT ion- pair species with chloroform after the first and second extractions of the aqueous phase. The extraction efficiency (E \%) was found to be $97.78 \%$.

Table 3.6. Absorbance of LD-EBT ion- pair after the first and second extractions

\begin{tabular}{lcccccc}
\hline $\begin{array}{l}\text { LD-HCL } \\
(\mathrm{mg} / \mathrm{L})\end{array}$ & $\% \mathrm{EBT}$ & $\mathrm{pH}$ & $\mathrm{A}_{1}$ & $\mathrm{~A}_{2}$ & Blank & Extraction efficiency (\%E) \\
\hline 10 & 0.1 & 1.8 & 0.921 & 0.065 & 0.007 & 97.78 \\
\hline
\end{tabular}

\subsubsection{Final Absorption Spectra}

After obtaining optimum conditions for the formation of the LD-EBT ion- pair, the final absorption spectra was checked. It was found that the color system had the same spectra as shown in Fig. (2.1). 


\subsubsection{Recommended Procedure}

A known volume of an aqueous sample of $\mathrm{LD}-\mathrm{HCl}$ was transferred to a $25 \mathrm{~mL}$ volumetric flask. Subsequently, $2 \mathrm{~mL}$ of buffer $\mathrm{pH} 1.8$ was added to the mixture and shaked well. Then $0.3 \mathrm{~mL}$ of $0.01 \%$ EBT was added to the mixture and diluted to the mark with distilled water. The diluted mixture was transferred to the separating funnel, and $5 \mathrm{~mL}$ of chloroform was added to the mixture. The mixture was shaked for $1 \mathrm{~min}$. afterwards; it was allowed to stand for clear separation of two layers of the two phases. The red chloroform layer was transferred into a glass cuvette .Absorbance of the red color ion -pair complex was measured at $508 \mathrm{~nm}$. The reagent blank was prepared in a similar way without LD-HCl.

\subsection{Validation of Proposed Method}

\subsubsection{Linearity}

Under the optimum experimental conditions, the absorbance vs. concentration plot was found to be a linear plot as shown in Fig 3.2.

The calibration curve shows that the extracted color system is obeyed Beer's Law within the concentration range of $0.1 \mathrm{mg} / \mathrm{L}-10 \mathrm{mg} / \mathrm{L}$. The linearity of calibration curves was proved by the high correlation coefficient value $\left(\mathrm{r}^{2}=0.9981\right)$. The interception of the calibration curve was very low, thus indicating that there occurred no systematic difference between determined and expected concentration within the investigated range using the proposed method. The apparent molar absorptivity $(\varepsilon)$ and Sandell's sensitivity were calculated and found to be $2.3623 \times 10^{4} \mathrm{~L} / \mathrm{mol} . \mathrm{cm}$ and 0.0122 $\mu \mathrm{g} / \mathrm{cm}^{2}$ respectively. The limits of detection and quantitation were found to be $0.024 \mathrm{mg} / \mathrm{L}$ and $0.100 \mathrm{mg} / \mathrm{L}$ respectively. These low values confirmed the good sensitivity of the proposed method. The statistical data of the calibration curve for spectrophotometric determination of $\mathrm{LD}-\mathrm{HCl}$ are shown in Table 3.7

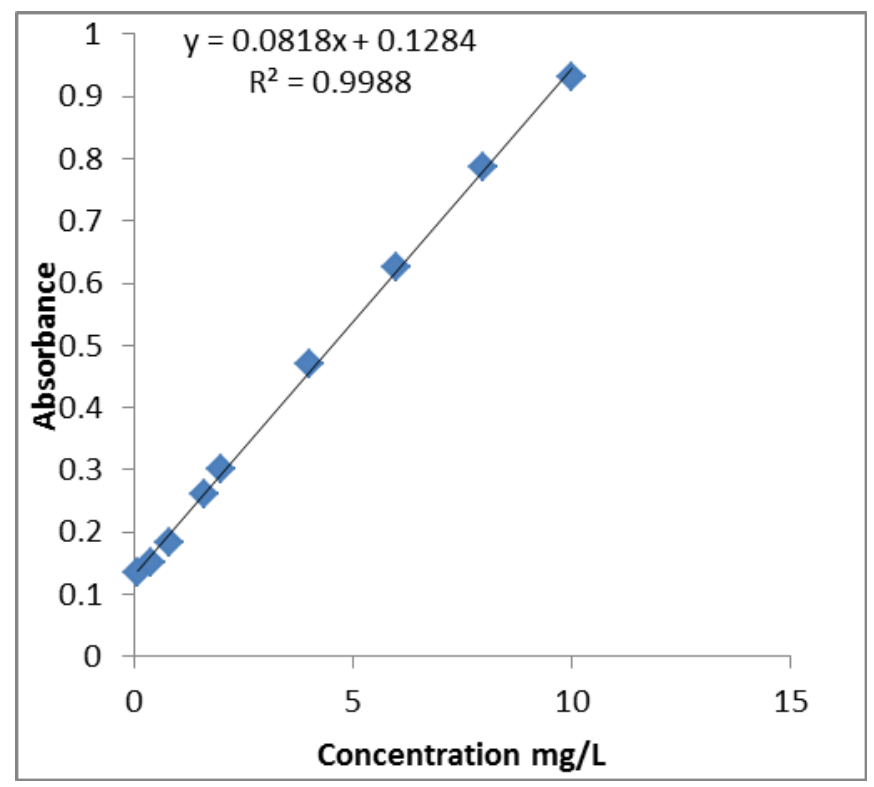

Figure 3.2. Calibration curve for spectrophotometric determination of LD-HCl

Table 3.7 Statistical data of the calibration curve for spectrophotometric determination of LD-HCl

\begin{tabular}{ll}
\hline$\lambda$ nm & 508 \\
\hline Linearity $\left(\mathrm{mg} . \mathrm{L}^{-1}\right)$ & $0.100-10.00$ \\
Detection Limit $\left(\mathrm{mg} . \mathrm{L}^{-1}\right), \mathrm{n}=6$ & 0.024 \\
Quantitation limit $\left(\mathrm{mg} . \mathrm{L}^{-1}\right)$ & 0.100 \\
Correlation coefficient, $\mathrm{R} 2$ & 0.9988 \\
Sandell's sensitivity, $\mu \mathrm{g} / \mathrm{cm} 2$ & 0.0122 \\
Molar absorptivity, $\mathrm{L} / \mathrm{mol} . \mathrm{Cm}$ & $2.3623 \times 10^{4}$ \\
\hline
\end{tabular}

\subsubsection{Accuracy and Precision}

Analysis was repeated at 3 different concentration levels $2 \mathrm{mg} / \mathrm{L}, 6 \mathrm{mg} / \mathrm{L}$, and $10 \mathrm{mg} / \mathrm{L}$ of $\mathrm{LD}-\mathrm{HCl}$ using the 
recommended procedure. The percentage recovery was calculated using the following equation:

$\mathrm{Er} \%=[($ founded - true $) /$ true $] \times 100$. The percentage recovery obtained was between $98 \%-102 \%$. The mean recovery value lies within $98 \%-100 \%$ indicating that the method was accurate. The precision was evaluated under the same operating conditions over a short interval of time. RSD \% was found to be between $0.25 \%-1.23 \%$. The value is below the $2 \%$, indicating that the method was repeatable. The results of accuracy and precision data are shown in table 3.8

Table 3.8. Accuracy data for LD-HCl obtained using the proposed method.

\begin{tabular}{ccccc}
\hline Concentration & Concentration of LD-HCl & \multicolumn{2}{c}{ Accuracy } & Precision \\
\cline { 4 - 5 }$(\mathrm{mg} / \mathrm{L})$ & Found $\pm \mathrm{SD}(\mathrm{mg} / \mathrm{L})$ & \%Recovery & \%Relative Error & \%RSD \\
2 & $2.04 \pm 0.026$ & 98 & 2.0 & 1.23 \\
6 & $6.09 \pm 0.015$ & 98.5 & 1.5 & 0.25 \\
& & & & \\
10 & $9.82 \pm 0.082$ & 101.8 & -1.8 & 0.84 \\
Mean & & 99.43 & 0.57 & \\
\hline
\end{tabular}

\subsubsection{Selectivity}

To assess the role of the inactive ingredients on the assay of LD-HCl sample, a synthetic mixture containing $(\mathrm{NaCl}$, benzyl alcohol, methyl paraben, and propyl paraben) was prepared and a known amount of LD- HCL was added. The drug was extracted and analyzed using the recommended procedures. The absorbance resulting from this solution was nearly the same as those obtained for pure LD-HCl solution was identical concentration. These results indicated that there is no interference from the inactive ingredients.

\subsection{Application}

The proposed method was applied for the quantification of $\mathrm{LD}-\mathrm{HCl}$ in four different commercial samples. The results were compared with the official LD-HCl quantification method (The US Pharmacopoeia, 2005), which uses HPLC UV with TRACER EXTRASIL ODS-2 $(5 \mu \mathrm{m}, 4.6-\mathrm{mm}$ and $15-\mathrm{cm})$ column. The results from the assay are given in Table 3.10. The concentrations of $\mathrm{LD}-\mathrm{HCl}$ samples determined with proposed methods was close to the concentration analyzed using official method.

Table 3.10. Determination of LD-HCl concentration in pharmaceutical samples

\begin{tabular}{llllll}
\hline Sample & $\begin{array}{l}\text { Label claim } \\
(\%)\end{array}$ & $\begin{array}{l}\text { Official method } \\
(\%)\end{array}$ & $\begin{array}{l}\text { Proposed method } \\
(\%)\end{array}$ \\
\cline { 2 - 6 } & & $\begin{array}{l}\text { Found } \\
(\mathrm{mg})\end{array}$ & $\begin{array}{l}\text { Recovery } \\
(\%)\end{array}$ & $\begin{array}{l}\text { Found } \\
(\mathrm{mg})\end{array}$ & $\begin{array}{l}\text { Recovery } \\
(\%)\end{array}$ \\
$\mathrm{A}$ & 2 & 1.86 & 93.00 & 1.84 & 92.00 \\
$\mathrm{~B}$ & 2 & 1.94 & 97.00 & 1.95 & 97.75 \\
$\mathrm{C}$ & 1 & 0.89 & 89.30 & 0.90 & 90.00 \\
$\mathrm{D}$ & 10 & 9.21 & 92.10 & 9.13 & 91.30 \\
\hline
\end{tabular}

\section{Conclusion}

The proposed method is accurate, precise, sensitive, simple, and cheap and can be used in both pure and pharmaceuticals samples determination without interference. Furthermore, the proposed method could be applied for the assay of $\mathrm{LD} \mathrm{HCl}$ in biological samples due to its low limit of detection. Finally the method provides advantages of stability even with slight variations in experimental conditions such as time, reagent concentration or temperature.

\section{References}

Abdelwahab, N. S., Nouruddin, W., Ali, M., Abdelkawy, M., \& Emam, A. A. (2016). Validated RP-HPLC and TLC-Densitometric Methods for Analysis of Ternary Mixture of Cetylpyridinium Chloride, Chlorocresol and Lidocaine in Oral Antiseptic Formulation. J. Chromatogr. Sci., 54(3), 318-325. https://doi.org/10.1093/chromsci/bmv144 
Aksu, Ö., Bozdoğan, A., \& Kunt, G. (2006). Simultaneous determination of mepyramine maleate, lidocaine hydrochloride, and dexpanthenol in pharmaceutical preparations by partial least - squares multivariate calibration. Analytical Letters, 39(4). https://doi.org/10.1080/00032710600611210

Amin, A. S., \& el-Didamony, A. M. (2003). Colorimetric determination of benzocaine, lignocaine and procaine hydrochlorides in pure form and in pharmaceutical formulations using p-benzoquinone. Anal. Sci., Oct; 19(10), 1457-1459. PMID: 14596417. https://doi.org/10.2116/analsci.19.1457

Asada, A. (1979). Gas chromatographic determination of local anesthetics in blood. Osaka City Med. J., 25, 91-122. PMID: 262781

Atay, O., \& Öztop, F. (1997). Quantitative Determination by Using HPLC and GLC Methods for Cocaine HCl in Synthetic Binary Mixtures with Procaine $\mathrm{HCl}$, Lidocaine $\mathrm{HCl}$ and Caffeine. Analytical Letters, 30(3). https://doi.org/10.1080/00032719708001802

Baniceru, M., Croitoru, O., \& Popescu, S. M. (2004). Determination of some local anesthetics in human serum by gas chromatography with solid-phase extraction. J. Pharm. Biomed. Anal., 35, 593-598. https://doi.org/10.1016/j.jpba.2004.02.012

Becker, D. E., \& Reed, K. L. (2006). Essentials of Local Anesthetic Pharmacology. Anesthesia Progress, 53(3), 98-109. https://doi.org/10.2344/0003-3006(2006)53[98:EOLAP]2.0.CO;2

Belal, T. S., \& Haggag, R. S. (2012). Gradient HPLC-DAD stability indicating determination of miconazole nitrate and lidocaine hydrochloride in their combined oral gel dosage form. J. Chromatogr Sci., May; 50(5), 401-409. PMID: 22407005. https://doi.org/10.1093/chromsci/bms019

Berkman, S., MacGregor, J., \& Alster, T. (2012). Adverse effects of topical anesthetics for dermatologic procedures. Expert Opin Drug Saf., May, 11(3), 415-23. doi: 10.1517/14740338.2012.669370. Epub 2012 Mar 8. Review. PMID: 22397312. https://doi.org/10.1517/14740338.2012.669370

Björk, M., Pettersson, K. J., \& Osterlöf, G. (1990). Capillary gas chromatographic method for simultaneous determination of local anaesthetics in plasma samples. J. Chromatogr., 533, 229-234. PMID: 2081770. https://doi.org/10.1016/S0378-4347(00)82207-0

Candioti, L. V., Robles, J. C., Mantovani, V'. E., \& Goicoechea, H. C. (2006). Multiple response optimization applied to the development of a capillary electrophoretic method for pharmaceutical analysis. Talanta, 69, 140-147. https://doi.org/10.1016/j.talanta.2005.09.021

Dołowy, M., Kulpińska-Kucia, K., \& Pyka, A. (2014). Validation of a Thin-Layer Chromatography for the Determination of Hydrocortisone Acetate and Lidocaine in a Pharmaceutical Preparation. The Scientific World Journal, 2014 Article ID 107879, 10. https://doi.org/10.1155/2014/107879

Drljača, D., Ašperger, D., Ferenčak, M., Gavranić, M., Babić, S., Mikac, I., \& Ahel, M. (2016). Comparison of Four Extraction Methods for the Determination of Veterinary Pharmaceuticals in Sediment. Chromatographia, February, 79(3-4), 209-223. https://doi.org/10.1007/s10337-015-3017-5

Edhorn, G. A. (1971). Determination of lidocaine in whole blood by gas chromatography. Can. Anaesth. Soc. J., 18, 189-198. PMID: 5572701. https://doi.org/10.1007/BF03025449

El-Ries, M. A., Abou, A. F. M., Abdel-Gawad, F. M., \& Abu El-Wafa, S. M. (1994). Preparation And Characterization Of $\mathrm{Cu}$ (Ii)-Lignocaine Complex. Indirect Estimation Of Lignocaine In Pharmaceutical Preparations By Atomic Absorption Spectroscopy (Aas). Journal of Pharmaceudcal \& Biomedical Analysis, 12(9), 1209-1213. https://doi.org/10.1016/0731-7085(94)80039-1

Feldmann, E. G., \& Koehler, H. M. (1959). The colorimetric determination of lidocaine with cis-aconitic anhydride. Journal of the American Pharmaceutical Association, 48(10), 549-552, October, 10. https://doi.org/10.1002/jps.3030481002

Gebauer, M. G., McClure, A. F., \&Vlahakis, T. L. (2001). Stability indicating HPLC method for the estimation of oxycodone and lidocaine in rectal gel. International Journal of Pharmaceutics, 223(1-2), 31 July, 49-54. https://doi.org/10.1016/S0378-5173(01)00729-3

Hassan, S. S., \& Ahmed, M. A. (1986). New liquid membrane electrode for determination of lidocaine in local anesthetic formulations. J. Assoc off Anal. Chem., Jul-Aug, 69(4), 618-20. PMID:3745087

Hattori, H., Yamamoto, S., \& Yamada, T. (1991). Determination of local anaesthetics in body fluids by gas chromatography with surface ionization detection. Journal of Chromatography B: Biomedical Sciences and Applications, 564(1) , 8 March, 278-282. https://doi.org/10.1016/0378-4347(91)80091-P 
Ionescu, M. S., Abrutis, A. A., Radulescu, N., Baiulescu, G. E., \& Coşofreţ, V. V. (1985). Lidocaine-selective membrane electrodes and their applications in pharmaceutical analysis. Analyst, 110, 929-931. https://doi.org/10.1039/AN9851000929

Ismaiel, S. A., Yassa, D. A., \& Gad-El-Rub, L. N. (1975). Spectrophotometric determination of lidocaine in some pharmaceutical preparations using bromocresol green. Pharmazie. Jun; 30(6), 408. PMID: 1161799

Jancic-Stojanović, B., Malenović, A., Marković, S., Ivanović, D., \& Medenica, M. (2010). Optimization and validation of an RP-HPLC method for analysis of hydrocortisone acetate and lidocaine in suppositories. J AOAC Int., Jan-Feb; 93(1), 102-107. PMID: 20334171

Jeffery, G. H., Bassett, J., Mendham, J., \& Cdenney, R. (1989). Quantitative Chemical Analysis VOGE L's (5 ${ }^{\text {th }}$ ed.). New York. John Wiley \& Sons.

John, Y., Frank, D., Bart, J., Angelo, M., \& Enid, N. (2011). Pharmacology and Therapeutics for Dentistry(6 $6^{\text {th }}$ ed.). Mosby.

Kadioglu, Y., Atila, A., Serdar, G. M., \& Alcan, A. N. (2013). Investigation of Behavior of Forced Degradation of Lidocaine $\mathrm{HCl}$ by NMR Spectroscopy and GC-FID Methods: Validation of GC-FID Method for Determination of Related Substance in Pharmaceutical Formulations. Iranian Journal of Pharmaceutical Research: IJPR, 12(4), 659-669. PMC: 3920691

Kang, L., Jun, H. W., \& McCall, J. W. (1999). HPLC assay of Lidocaine in plasma with solid phase extraction and UV detection. Journal of Pharmaceutical and Biomedical Analysis, 19(5), April, 737-745. https://doi.org/10.1016/S0731-7085(98)00298-2

Keenaghan, J. B. (1968). The determination of lidocaine and prilocaine in whole blood by gas chromatography. Anesthesiology, 29, 110-112. PMID: 5634553. https://doi.org/10.1097/00000542-196801000-00029

Koster, E. H. M., Hofman, N. S. K., \& Jong, G. J. (1998). Direct solid-phase microextraction combined with gas and liquid chromatography for the determination of lidocaine in human urine. Chromatographia, 47(11-12), 678. https://doi.org/10.1007/BF02467453

Kruczek, M. E. (1981). A rapid gas-liquid chromatographic determination of serum lidocaine using a nitrogen-phosphorus specific detector. J. Pharmacol. Methods, 5, 137-141. PMID: 7230837. https://doi.org/10.1016/0160-5402(81)90005-X

Kumar, K. B., Rajan, T. V. S., \& Begum, T. N. (2012). Analytical method development and validation of lidocaine in ointment formulation by U.V spectrophotometric method. International Journal of Pharmacy and Pharmaceutical Sciences, 4(2), 610-614.

Liawruangrath, S., Liawruangrath, B., \& Pibool, P. (2001). Simultaneous determination of tolperisone and lidocaine by high performance liquid chromatography. Journal of Pharmaceutical and Biomedical Analysis, 26(5-6), December, 865-872. https://doi.org/10.1016/S0731-7085(01)00462-9

Lotfy, H. M., Tawakkol, Sh. M., Fahmy, N. M., \& Shehata, M. A. (2013). Validated stability indicating spectrophotometric methods for the determination of lidocaine hydrochloride, calcium dobesilate, and dexamethasone acetate in their dosage forms. Analytical Chemistry Letters, 3(3). https://doi.org/10.1080/22297928.2013.838428

Malenovic, A., Medenica, M., Ivanovic, D., Jancic, B., \& Markovic, S. (2005). Development and validation of RP-HPLC method for cetrimonium bromide and lidocaine determination. Il Farmaco, 60(2), February, 157-161. https://doi.org/10.1016/j.farmac.2004.11.004

Martindale. (2007). The complete drug reference ( $35^{\text {th }}$ ed.) Pharmaceutical press London, UK.

Mohammad, A. M. (2009). LC Determination of Lidocaine and Prilocaine Containing Potential Risky Impurities and Application to Pharmaceuticals. Chromatographia, August, 70(3-4), 563-568. https://doi.org/10.1365/s10337-009-1173-1

Němcová, I., Rychlovský, P., Tománková, V., \& Živanovič, L. J. (2001). Extraction spectrophotometric determination of lidocaine using flow injection analysis. Analytical Letters, 34(14). https://doi.org/10.1081/AL-100107527

Nerín, C., Garnica, A., \& Cacho, J. (1991). Indirect Determination of Lidocaine by Atomic Absorption Spectrophotometry. Analytical Letters, 24(10). https://doi.org/10.1080/00032719108053017

Ohshima, T., \& Takayasu, T. (1999). Simultaneous determination of local anesthetics including ester-type anesthetics in human plasma and urine by gas chromatography-mass spectrometry with solid-phase extraction. Journal of 
Chromatography B: Biomedical Sciences and Applications. 16 April, 726(1-2), 185-194. https://doi.org/10.1016/S0378-4347(98)00510-6

Oliveira, R. T. S., Salazar-Banda, G. R., Ferreira, V. S., Oliveira, S. C., \& Avacaa, L. A. (2007). Electroanalytical Determination of Lidocaine in Pharmaceutical Preparations Using Boron-Doped Diamond Electrodes. Electroanalysis, 19(11), 1189-1194. https://doi.org/10.1002/elan.200603840

Parissi-Poulou, M., \& Panderi, I. (1999). Determination of hyoscine n-butyl-bromide, lidocaine hydrochloride, and paracetamol in injection forms using solid-phase extraction, high-performance liquid chromatography, and uv-vis spectrophotometry. Journal of Liquid Chromatography \& Related Technologies, 22(7). https://doi.org/10.1081/JLC-100101717

Pendela, M., Kahsay, G., Baekelandt, I., Van Schepdael, A., \& Adams, E. (2011). Simultaneous determination of lidocaine hydrochloride, hydrocortisone and nystatin in a pharmaceutical preparation by RP-LC. J. Pharm. Biomed. Anal., Nov 1; 56(3), 641-644. Epub 2011 Jul. 5. https://doi.org/10.1016/j.jpba.2011.06.028

Prat, M., \& Bruguerolle, B. (1986) Rapid simultaneous gas-liquid chromatographic determination of five local anesthetic drugs in serum. Clin. Chem., Nov; 32(11), 2098. PMID: 3779952

Putta, M., Gurupadayya, B. M., Disha, N. S., \& Sama, S. ( 2013). Spectrophotometric determination of lidocaine in bulk and pharmaceutical formulations. Inventi:ppaqa/573/12.

Rahbar, N., Ramezani, Z., \& Jundishapur, A. B. (2015). Electro-Oxidation Mechanism and Direct Square-Wave Voltammetric Determination of Lidocaine with a Carbon-Paste Electrode. J. Nat. Pharm. Prod., February; 10(1), e19382. https://doi.org/10.17795/jjnpp-19382

Railan, D., \& Alster, T. S. (2007). Use of topical lidocaine for cosmetic dermatologic procedures. J. Drugs Dermatol., Nov; 6(11), 1104-1108. Review.PMID:18038497.

Rizk, M. S., Issa, Y. M., Shoukry, A. F., \& Atia, E. M. (1997). Spectrophotometric Determination of Lignocaine in Pure Form and in Pharmaceutical Preparations. Analytical Letters, 30(15). https://doi.org/10.1080/00032719708001818

Salas, S., Talero, B., Rabasco, A. M., \& González, M. L. (2008). Development and validation of a reverse-phase liquid chromatographic method for the assay of lidocaine hydrochloride in alginate-Gantrez ${ }^{\mathbb{B}}$ microspheres. Journal of Pharmaceutical and Biomedical Analysis, 47(3), 15 July, 501-507. https://doi.org/10.1016/j.jpba.2008.01.045

Saleh, G. A., \& Askal, H. F. (1995). Spectrophotometric Determination of Certain Local Anaesthetics in Pharmaceutical Preparations. Pharmaceutical Analysis, 2663-2671. https://doi.org/10.1080/00032719508007417

Shaalan, R. A., \& Belal, T. S. (2010). HPLC-DAD stability indicating determination of nitrofurazone and lidocaine hydrochloride in their combined topical dosage form. J. Chromatogr Sci., Sep; 48(8), 647-653. PMID: 20819294. https://doi.org/10.1093/chromsci/48.8.647

Smith, F. M., \& Nuessle, N. O. (1981). Hplc Method for Determination of Lidocaine in Admixture with Dextrose Injection. Analytical Letters, 14(8). https://doi.org/10.1080/00032718108055470

Stavchansky, S., Eghbali, B., \& Geary, R. (1987) .Stability Indicating Assay of Lidocaine Hydrochloride in Solution. Analytical Letters, 20(5). https://doi.org/10.1080/00032718708062931

Tarli, P., Benocci, S., \& Neri, P. (1969). Gas chromatographic determination of nicotinamide and lidocaine in pharmaceutical preparations. Boll Chim Farm. Sep; 108(9), 554-559. PMID: 4243671

The United States Pharmacopia, 32 nd. ed., NF- 27 Asian Edition, 3, (2008) p. 2781.

Thomas, L., Lemke, D., \& Williams, A. (2008). Foye's principles of medicinal chemistry $\left(6^{\text {th }}\right.$ ed.). Philadelphia: Lippincott Williams \& Wilkins.

Waraszkiewicz, S. M., Milano, E. A., \& DiRubio, R. (1981). Stability-indicating high-performance liquid chromatographic analysis of lidocaine hydrochloride and lidocaine hydrochloride with epinephrine injectable solutions. J. Pharm. Sci., Nov; 70(11), 1215-1218. PMID: 7299666. https://doi.org/10.1002/jps.2600701109

Watanabe, T., Namera, A., Yashiki, M., Iwasaki, Y., \& Kojima, T. (1998). Simple analysis of local anaesthetics in human blood using headspace solid-phase microextraction and gas chromatography-mass spectrometry-electron impact ionization selected ion monitoring. Journal of Chromatography B: Biomedical Sciences and Applications, 709(2), 29 May, 225-232. https://doi.org/10.1016/S0378-4347(98)00081-4

Wen, T. W., Xiao, L. X., \& Shu, M. L. (2014) .Determination of Lidocaine Hydrochloride Injection by Liquid-Liquid Extraction-Fluorimetry. College of Chemistry \& Life Science, Quanzhou Normal University, 06.

Youngvises, N., Liawruangrath, B., \& Liawruangrath, S. (2003). Simultaneous micellar LC determination of lidocaine 
and tolperisone. J. Pharm. Biomed. Anal., 31, 629-638. PMID: 12644189.

https://doi.org/10.1016/S0731-7085(02)00693-3

Zivanovic, L. J., Zecevic, M., Markovic, S., Petrovic, S., \& Ivanovic, I. (2005). Validation of liquid chromatographic method for analysis of lidocaine hydrochloride, dexamethasone acetate, calcium dobesilate, buthylhydroxyanisol and degradation product hydroquinone in suppositories and ointment. Journal of Chromatography A, 1088(1-2), 23 September, 182-186. https://doi.org/10.1016/j.chroma.2005.04.049

Živanović, L. J., Živanov-Stakić, D., \& Radulović, D. (1988). Comparision of high-performance and thin-layer chromatographic methods for the assay of lidocaine. Journal of Pharmaceutical and Biomedical Analysis, 6(6-8), 809-812. https://doi.org/10.1016/0731-7085(88)80095-5

Zong, H. Q., Li, J. P., \& Rong, T. (2007) .Spectrophotometric Method for Determining Lidocaine Hydrochloride with Eosin Methylene Blue. Journal of Jiangxi Normal University (Natural Science Edition), 3.

\section{Copyrights}

Copyright for this article is retained by the author(s), with first publication rights granted to the journal.

This is an open-access article distributed under the terms and conditions of the Creative Commons Attribution license (http://creativecommons.org/licenses/by/4.0/). 